\title{
Ireneusz Krzemiński (red.), Żydzi - problem prawdziwego Polaka. Antysemityzm, ksenofobia i stereotypy narodowe po raz trzeci, War- szawa: Wydawnictwa Uniwersytetu Warszawskiego, 2015, s. 220.
}

DOI: http://dx.doi.org/10.12775/PCh.2016.018

Prosta biała okładka - a na niej czarny szkic przedstawiający dwoje krępych, bogato ubranych Żydów wyśmiewających ubogą, nędznie ubraną polską rodzinę z małym dzieckiem, będący fragmentem ulotki antysemickiej wydanej przez Stronnictwo Narodowe w Poznaniu, pochodzącej ze zbiorów Archiwum Żydowskiego Instytutu Historycznego im. Emanuela Ringelbluma - przyciaga uwagę potencjalnego czytelnika. Równie silnie oddziałuje tytuł książki: Żydzi - problem prawdziwego Polaka. Jej wnikliwa lektura daje podstawy, aby stwierdzić, iż jest to pierwsze kompleksowe opracowanie materiału, jaki przyniosły badania nad antysemityzmem prowadzone na przestrzeni blisko dwudziestu lat od przełomu politycznego w Polsce. Praca zespołu socjologów z Uniwersytetu Warszawskiego stawia między innymi odważne pytania o to: czy demokracja sprzyja odrzucaniu wrogości wobec Żydów? jak na antysemityzm wpływa polska religijność? czy imperium medialne o. Tadeusza Rydzyka jest źródłem postaw antysemickich? czym jest wtórny antysemityzm, a czym tak zwany nowy antysemityzm antyizraelski? czy Polacy odrzucają prawdę na temat polskiej zbrodni w Jedwabnem?

Monografia prezentuje wyniki badań z 2012 roku (rezultaty realizacji grantu Narodowego Centrum Nauki). Zostały one porównane z danymi z lat 1992 i 2002. Redaktor naukowy tomu, socjolog Ireneusz Krzemiński, zajmuje się problemem antysemityzmu od wielu lat i należy do grona najbardziej cenionych badaczy tego obszaru ${ }^{1}$. Opatrzył on książkę wstępem i wprowadzeniem zatytułowanym Antysemityzm, ksenofobia $i$ stereotypy narodowe po raz trzeci. Jest także autorem pierwszego artykułu: Uwarunkowania i przemiany postaw antysemickich. Wyniki badań wskazuja, że z jednej strony demokracja sprzyja odrzucaniu wrogości wobec Żydów, ponieważ

${ }^{1}$ Por. Czy Polacy sq antysemitami?: wyniki badania sondażowego, red. Ireneusz Krzemiński (Warszawa: Oficyna Naukowa, 1996); Antysemityzm w Polsce i na Ukrainie: raport z badań, red. Ireneusz Krzemiński (Warszawa: Wydawnictwo Naukowe Scholar, 2004). 
odsetek antysemitów spadł znacząco w porównaniu z 2002 rokiem. Postawę antysemityzmu nowoczesnego (wskazującego na zbytnią dominację Żydów w gospodarce, polityce czy mediach oraz antyizraelskość) prezentowała $1 / 5$ badanych (w 2002 roku - 1/3), natomiast antysemityzm tradycyjny (wrogość do Żydów uzasadniana tradycyjnymi chrześcijańskimi stereotypami religijnymi) to zaledwie $8 \%$ badanych (w 2002 roku - 11,6\%). Znamienne jest, iż Ireneusz Krzemiński zaobserwował wzrost postaw, które nazwał anty-antysemityzmem: „takich deklaracji, które odrzucają wszelkie oskarżenia wobec Żydów zawarte w pytaniach. Niechęć do oskarżycielskich stereotypów rośnie wyraźnie na przestrzeni lat i obecnie dorównuje odsetkowi antysemitów" (s. 24)2.

Analizując dane statystyczne (uwzględniające takie kryteria jak: wykształcenie, wiek, religijność, warunki materialne, miejsce zamieszkania, poczucie dumy narodowej, poglądy na rolę Kościoła, opcje polityczne), sformułowano podstawową tezę raportu, mówiącą o tym, że antysemityzm stał się częścią szerszego światopoglądu ideologicznego, nazwanego światopoglądem narodowo-katolickim (s. 57). W drugim artykule pod tytułem: Szczególne uprawnienia kościoła katolickiego a antysemityzm, jego autor, Rafał Duluk, decyduje się na prezentację surowych danych empirycznych, bez szerszego komentarza. Z licznych zestawień tabelarycznych można jednakże stworzyć obraz osoby reprezentującej najsilniejsze postawy antysemickie: jest to najczęściej starszy mężczyzna, pobierający emeryturę lub rencista, legitymizujący się wykształceniem podstawowym, zamieszkujący miasta średnie lub wieś, czytelnik Naszego Dziennika bądź Faktu, pesymistycznie oceniający sytuację ogólną w Polsce i własną, preferujący wychowanie dzieci do posłuszeństwa. Jednocześnie akceptuje on szczególny wpływ Kościoła katolickiego na prawo i przepisy obowiązujące w Polsce, jest również osobą deklarującą głęboką religijność, często związany ze środowiskiem Radia Maryja.

Z kolei Jowita Wiśniewska skoncentrowała się w swoich badaniach na opiniach dotyczących mordu w Jedwabnem (artykuł trzeci). Interesowały ją między innymi społeczne reperkusje książki Jana T. Grossa pod tytułem $S a-$ siedzi, która wywołała, jej zdaniem, jedną z najgorętszych debat rozrachunkowych o przeszłości w Polsce. Zestawiając wyniki badań z 2002 i 2012 roku stwierdza między innymi, że „w okresie 10 lat społeczeństwo polskie

2 Nowoczesny anty-antysemityzm wyniósł $21 \%$ w 2012 roku (16\% - 2002 roku), tradycyjny anty-antysemityzm - 45\% w 2012 roku (35\% - 2002 roku). 
nie zmieniło zdania co do wydarzeń w Jedwabnem. Nadal istnieją przede wszystkim dwie silne grupy, których opinie na temat mordu w Jedwabnem wzajemnie się wykluczają choć warto zauważyć malejącą tendencję wśród reprezentacji odrzucającej [tzn. opinie dezawuujące wydarzenia w Jedwabnem oraz szukające wyjaśnień zbrodni w czynnikach zewnętrznych - przyp. J. C.-S.], a więc i usprawiedliwiającej zbrodnię jedwabieńską" (s. 101). Druga grupa osób poszukuje wyjaśnień w czynnikach wewnętrznych (ideologii narodowej, zemście, motywach majątkowych oraz we współpracy Żydów z Sowietami po kampanii wrześniowej). Jowita Wiśniewska zwróciła również uwagę na fakt, iż ponad 30\% respondentów nie ma jednoznacznego stanowiska $\mathrm{w}$ ocenie tego bolesnego wydarzenia w historii relacji polsko-żydowskich. Szczególnie niepokojące jest jednak, że postawę odrzucającą prezentują głównie ludzie młodzi (18-24 lata). Stanowi to ogromne wyzwanie dla edukacji szkolnej, która jak dotąd - w opinii autorki - prawie w ogóle nie znajduje miejsca dla tematu mordu w Jedwabnem w programie szkolnym.

Zbyt powierzchowna edukacja historyczna prowadzi często do jednostronnego interpretowania przeszłości. Tym zagadnieniom Adrian D. Wójcik poświęca kolejny artykuł w omawianym tomie zbiorowym. Użyta w badaniach 4-stopniowa skala Likerta potwierdza, że Polacy raczej akceptują odpowiedzi dotyczące instrumentalizacji historii przez stronę żydowską do osiagnięcia teraźniejszych celów (m.in. „Żydzi chcą zdobyć od Polaków odszkodowanie za coś, co w rzeczywistości uczynili Niemcy” - 2,42; „Żydzi rozpowszechniają pogląd, że Polacy są antysemitami” - 2,09; „Denerwuje mnie, gdy dziś wciąż mówi się o zbrodniach popełnianych przez Polaków na Żydach"-2,59). I są to poglądy rozpowszechnione wśród różnych grup społecznych, niezależnie od płci, wieku i dochodów. Autor raportu reprezentuje stanowisko, iż może to być wskaźnik wtórnego antysemityzmu, jak również efekt bardziej ogólnej tendencji, „syndromu naiwnych reprezentacji historii w ogóle" (s. 131).

Jednocześnie Polacy idealizują własną historię oraz rolę, jaką odgrywali w relacjach polsko-żydowskich. Niezwykle interesujący wizerunek naszego społeczeństwa wyłania się z eksploracji Krzysztofa Chomickiego, Marcina Jóźki i Wojciecha Ogrodnika Polaków portret własny, Polaków portret innych. Stereotypy narodowe w świetle badań empirycznych. Poznajemy w nim autostereotyp, jak również główne składowe stereotypu Żydów, Niemców, Rosjan, Ukraińców oraz Romów (pytano oddzielnie o cechy ludzkie oraz cechy narodowe). Atutem tych badań jest zastosowanie serii pytań otwartych, co powoduje, iż nie ograniczamy respondenta w repertuarze odpowiedzi, 
ale również nie generujemy sztucznie za pomocą kwestionariusza negatywnych cech danej społeczności. Nie zdradzając wszystkich efektów dociekań, nadmieńmy w tym miejscu jedynie, że najbardziej pozytywny stereotyp (zarówno w przypadku cech zbiorowych, jak i indywidualnych) mamy wobec siebie samych...

Artykuł szósty napisany przez Dominika Wasilewskiego pod tytułem: Frustracja i gniew a atrakcyjność skrajnej ideologii. Społeczne źródła aktów przemocy wobec imigrantów oraz agresji słownej wobec znanych postaci życia publicznego w oczach studentów to bardzo pesymistyczny obraz rozwoju postaw skrajnie narodowych wśród młodzieży. Ilustracją dla tych procesów stały się wydarzenia we Wrocławiu (przerwanie wykładu prof. Zygmunta Baumana przez działaczy Narodowego Odrodzenia Polski) oraz akty agresji wobec imigrantów w Białymstoku w 2013 roku. Autor przywołuje liczne komentarze prasowe przedstawiające te wydarzenia oraz fragmenty wywiadów fokusowych, przeprowadzonych w grupach studenckich obu miast. Manifestacje środowiska narodowców, które odbyły się w Białymstoku w maju 2016 roku (tj. już po ukazaniu się niniejszej książki) potwierdzają, że tym procesom socjologia musi przyjrzeć się bardziej wnikliwie.

W ostatnim artykule Jerzy Bartkowski zastanawia się nad obecnością mniejszości żydowskiej w sferze publicznej - czy istnieje społeczne przyzwolenie, aby Żyd mógł zostać kandydatem na prezydenta, inwestorem lub właścicielem ziemi? W odpowiedzi dowiadujemy się, że: „postawy wobec obecności osób pochodzenia żydowskiego w sferze publicznej są niechętne. Przeciętny respondent nie zagłosowałby na taką osobę w wyborach prezydenckich, niechętnie widziałby ją jako właściciela przedsiębiorstwa w naszym kraju i byłby przeciw sprzedaży jej polskiej ziemi” (s. 200). Przy czym to negatywne nastawienie uwidacznia się również wobec osób z innym niepolskim pochodzeniem (w przypadku funkcji prezydenta - będą to także Niemcy, Rosjanie i Ukraińcy) ${ }^{3}$.

Nie sposób przywołać wszystkich najważniejszych rezultatów badań. Recenzowany tom wypełniony jest danymi empirycznymi i tabelami. To ogrom materiału badawczego, wygenerowany przez ekspertów posługujących się solidnymi narzędziami, wzbogacony o wnikliwe analizy i interpretacje. Z tego względu zapewne jego odbiorców należy szukać przede wszystkim wśród socjologów i wyrafinowanych czytelników, którzy chcą zmierzyć

${ }^{3}$ Respondenci mieli możliwość określenia swojej akceptacji osoby pochodzenia niepolskiego jako prezydenta spośród czterech narodowości: Żydów, Niemców, Rosjan i Ukraińców. 
się z badaniami socjologicznymi na najwyższym poziomie. Są to jednak niezmiernie istotne kwestie społeczne, które z całą pewnością zasługują na upowszechnienie w naszym społeczeństwie.

Joanna Cukras-Stelagowska*

\section{Bibliografia}

Czy Polacy sq antysemitami?: wyniki badania sondażowego, red. Ireneusz Krzemiński. Warszawa: Oficyna Naukowa, 1996.

Antysemityzm w Polsce i na Ukrainie: raport z badań, red. Ireneusz Krzemiński. Warszawa: Wydawnictwo Naukowe Scholar, 2004.

Żydzi - problem prawdziwego Polaka. Antysemityzm, ksenofobia i stereotypy narodowe po raz trzeci, red. Ireneusz Krzemiński. Warszawa: Wydawnictwa Uniwersytetu Warszawskiego, 2015.

Norbert N. Pikuła, Poczucie sensu życia osób starszych. Inspiracje do edukacji w starości, Kraków: Oficyna Wydawnicza „Impuls”, 2015, s. 218.

DOI: http://dx.doi.org/10.12775/PCh.2016.019

Nakładem Oficyny Wydawniczej „Impuls” ukazała się w 2015 roku książka Norberta N. Pikuły pod tytułem: Poczucie sensu życia osób starszych. Inspiracje do edukacji w starości. Jej autor jest teologiem i gerontologiem. Obecnie pełni funkcję dyrektora Instytutu Pracy Socjalnej na Wydziale Pedagogicznym Uniwersytetu Pedagogicznego im. Komisji Edukacji Narodowej w Krakowie. Celem podjętych przez niego badań było poznanie i opisanie „sensu życia seniorów w kontekście ich wieku, potrzeb, miejsca zamieszkania (Polska/Kanada), celów życiowych, relacji społecznych, duchowości oraz poczucia własnej wartości” (s. 82).

$\mathrm{Na}$ recenzowaną książkę składają się cztery rozdziały. W pierwszym, zatytułowanym „Życie osób starszych w czasach zmiany społecznej”, przed-

* Dr Joanna Cukras-Stelagowska jest adiunktem w Katedrze Teorii Wychowania na Wydziale Nauk Pedagogicznych Uniwersytetu Mikołaja Kopernika w Toruniu. Adres: Wydział Nauk Pedagogicznych UMK, ul. Lwowska 1, 87-100 Toruń; e-mail: joanstel@umk.pl. 